Note that the technical rotation is lengthened or shortened by more than the amount of the regeneration delay or gain; that is to say, cutting age for effective maximum m.a.i. over the rotation (or cutting cycle) is increased for a regeneration delay and reduced for a regeneration gain as compared with the cutting age for volume over age, maximum.

Other graphs could be drawn for situations where partial cuts are taken, where advanced immature is partly destroyed or where the natural curve of volume over age is otherwise expected to be distorted under management.

The absence of the precise point of intersection which is always illustrated on plots of the p.a.i. curve superimposed on the m.a.i. curve should be no cause for concern. A truer picture is presented in these illustrations for the zone of near-tangency between the line of maximum slope and volume over age curve simply illustrates the fact that cutting age may be varied through this zone for production of desired products without significant loss in yield capacity.

The method of deriving technical rotation, cutting age, and effective mean annual increment from volume over age data by the graphical method here illustrated should have many practical applications.

\title{
AWARDS
}

1960 C. I. F. Gold Medal Winners

UNIVERSITY OF NEW BRUNSWICK

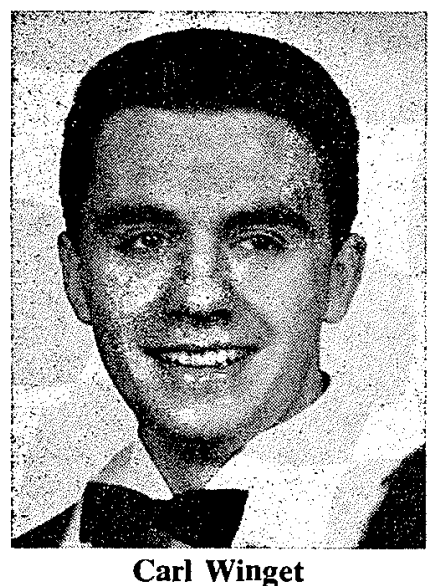

Carl H. Winget was born on September 28, 1939, in Noranda, Quebec. He received grade school and high school education at Lennoxville High School, Lennoxville, Quebec and graduated in 1955 and entered U.N.B.'s Forestry course in the same year. Winget worked for the Ontario Dept. of Lands and Forests in 1956 and for the Federal Forestry Branch in 1958 and 1959. He received the Schlick Memorial Fund Award and the Quebec North Shore Paper Co. Scholarship in 1959. Carl is now attending the University of Wisconsin on a research assistantship and taking a master's degree in silviculture. 


\section{LAVAL UNIVERSITY}

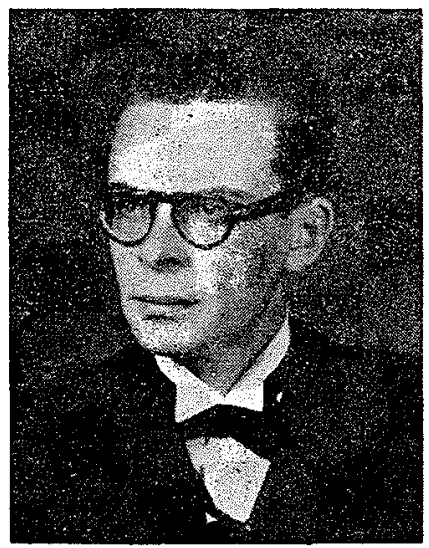

Damien Bourgoin

Damien Bourgoin was born June 8, 1933, at Riviere-Verte, Quebec, the son of E. Bourgoin, mechanic. His studies were first pursued at Riviere-Verte up to Junior High School level, then he obtained his registration at the Mgr. Tache Classical College in Riviere-du-Loup where he studied for two years before transferring to Ste Anne de la Pocatiere College from which he graduated in June, 1956, with the degree of Bachelor of Arts.

He entered the Faculty of Surveying and Forest Engineering the following September, being awarded the degree of Bachelor of Applied Science (Forest Engineering) "Magna cum laude" in June, 1960.

For high academic achievement and general proficiency, Mr. Bourgoin was awarded the Donnacona Paper Company Scholarship in 1958-59 and again in 1959-60.

Damien Bourgoin has spent his summer vacations with the Fédéral Forest Service in New-Brunswick during 1957, and with Consolidated Paper Corporation on forest inventory work during 1958 and $1959 . \mathrm{He}$ is interested in Silviculture and forest plantations and his graduation thesis: "Mineral content of leaves in Red Pine plantations" is a valuable addition to our knowledge of this question.

Damien is now with Consolidated Paper Corporation having joined their Forestry Department immediately upon graduation.

\section{UNIVERSITY OF TORONTO}

Lambertus Johannes Post, is the son of Mr. and Mrs. J. G. Post of the Netherlands. Bert Post is 31 years old. He came to Canada in 1951 after completing his secondary education at the State Agricultural School in Utrecht, Holland, and entered the Faculty of Forestry in September 1956.

During his undergraduate years Bert Post has been outstanding academically and as a leader in student affairs. His academic achievements include the winning of the P. D. Leslie Scholarship, the Harold S. Edmonds Prize, 


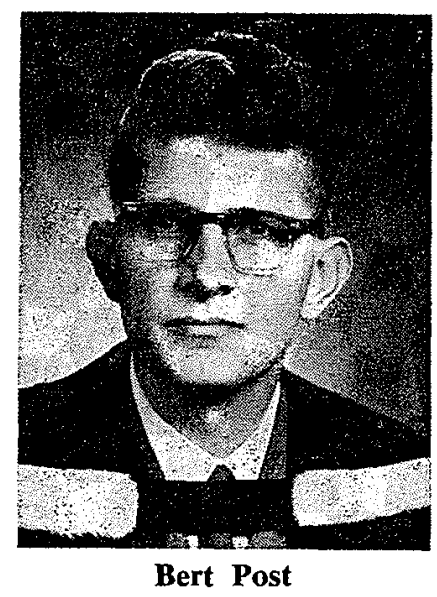

the Spruce Falls Power \& Paper Co. Ltd. Biological Scholarship for Second Year, the White Pine Bureau Scholarship, and the University of Toronto Alumni War Memorial Scholarship (Forestry). Mr. Post has taken an active part in interfaculty sports and also in connection with the Foresters' Club, of which he was Treasurer during the session 1957-58. He proved to be a valuable assistant in the re-organization of the classification system of the Faculty Library, where he was employed on a part-time basis.

Mr. Post has accepted a position with the silvicultural research division of the Forestry Branch with headquarters in Fredericton, New Brunswick.

\section{The UnIversity of British Columbia}

William John Revel was born on January 6, 1935 in Belfast, North Ireland. His family made their home at Enderby, B.C. after emigrating to Canada.

John was the leader of the B.S.F. graduating class of 1960 with an exceptionally high average, 86.0 per cent. Throughout his studies at U.B.C. John combined an excellent scholastic record with active participation in the Forest Club, the Varsity Outdoor Club, and Church and Young People's Groups. He even found time to consult on logging layout during the Christmas "holidays".

Gaining his Senior Matriculation certificate from Vernon High School in 1952, John worked for the B.C. Forest Service for three years and was Assistant Ranger at Blue River. He gained valuable industrial experience while employed by Eagle Pass Timbers Ltd. and Western Plywood (Cariboo) Ltd. At the present time he is learning first hand about slash burning and the growth and harvest of the giant Douglas firs of the Nimpkish Valley as an assistant forester in charge of protection for the Englewood Logging Division of Canadian Forest Products Ltd.

John has won several academic awards including the H. R. MacMillan Prize and the Galt Elkington Scholarship. He plans on post graduate training, probably commencing in 1962 . 


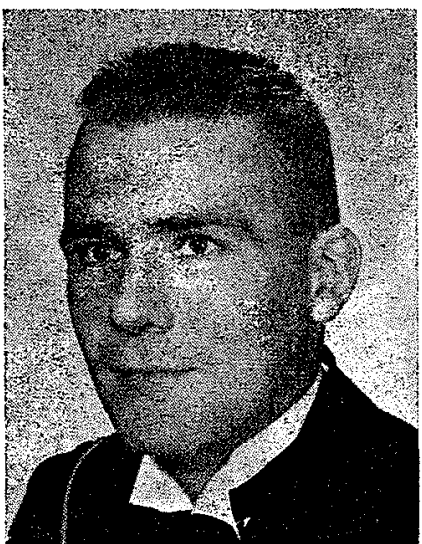

John Revel

John has accepted the challenge to work all of his life for betterment of our forests in Canada. We wish him well and expect much of him!

\section{UNIVERSITY OF TORONTO SCHOLARSHIPS}

The following awards were made:

The Osmose Wood Preserving scholarship of $\$ 250$ to Ralph Patrick Yanni. The P. D. Leslie scholarship of $\$ 100$ to Lambertus Johannes Post. The F. K. Morrow forestry scholarship of $\$ 250$ to Edward Bruce Mac Dougall. The Goodman scholarship of $\$ 100$ to Charles Van Wagner. The R. P. Wright memorial scholarship of $\$ 150$ to Charles Edward Van Wagner. Spruce Falls scholarships of $\$ 300$ to Charles Edward Van Wagner, of $\$ 300$ to Edward Bruce MacDougall, of $\$ 300$ to Berend Jan Veldhoen, of $\$ 400$ to Ian Kenneth Morrison. The Harold S. Edmonds prize to Ian Kenneth Morrison. The White Pine Bureau scholarship of $\$ 100$ to Lawrence Thomas Kirby.

\section{University of British Columbia Scholarships}

The following awards were made: Finning Tractor $\$ 250$ to Kenueth John Mitchell; Finning Tractor $\$ 250$ to James Glenister Bullen; Galt Elkington $\$ 350$ to Kenneth Gordon Derek Green; H. R. MacMillan $\$ 200$ to Brodie Swan, $\$ 100$ to Lorne Brace, $\$ 200$ to Orest Allan Novik, \$100 to Ronald Charles Kowall; Rayonier $\$ 500$ to Ronald W. Haigh; Western Plywood $\$ 125$ to Herbert Percival Sims, $\$ 125$ to Gordon Balfour Squire.

For your convenience The Forestry Chronicle offers a free employment service. Prospective employers or applicants should write to Mr. George A. Sinclair, Ontario Department of Lands \& Forests, Tweed, Ontario, who will prepare applications for poblication. Applicants are requested to include their own advertisement giving the following information: University granting degree, year of graduation, years and type of experience and type of employment preferred. 